\title{
O Impacto da Dívida Pública sobre o Spread Bancário: uma Avaliação Empírica*
}

\section{The Impact of Public Debt on Banking Spread: an Empirical Assessment}

\author{
Rodrigo dos Santos Branco** \\ Luiz Fernando de Paula***
}

\begin{abstract}
Resumo: Este trabalho objetiva investigar a influência que as Letras Financeiras do Tesouro Nacional (LFT) podem ter sobre o spread bancário brasileiro no período 20012011. A hipótese subjacente é que a existência de títulos públicos atrelados diretamente à taxa básica de juros Selic inibe a ampliação de um mercado de crédito mais pujante, dado que são títulos de baixo risco e com rentabilidade capaz de inibir a concessão de empréstimos com taxas de juros menores, face ao maior risco inerente às operações de crédito. O artigo mostra evidências empíricas, através de um modelo de mínimos quadrados ordinários em dois estágios (MQ2E), de que a taxa Selic e a emissão de LFT impactam sobre os níveis do spread bancário no Brasil.
\end{abstract}

Palavras-chave: Spread bancário. Títulos públicos. Dívida pública.

\begin{abstract}
This paper aims at evaluating the influence that the National Financial Treasury Bonds (Letras Financeiras do Tesouro Nacional - LFT) may have on the banking spread in Brazil between 2001 and 2011. The main hypothesis is that the existence of public bonds directly linked to the basic interest rate (Selic) inhibits the growth of the credit market, since they are low risk and profitable bonds that restrict credit granting with lower interest rates, due to the greater operational risk inherent to credit operations. The article show empirical evidences, using a model of 2-Stage Least Squares, that Selic rate and the issue of the LFT contribute for the high levels of banking spread in Brazil.
\end{abstract}

Keywords: Banking spread. Net interest margins. Public debt.

JEL Classification: G21; G28; H63.

Os autores agradecem as sugestões feitas por um parecerista anônimo, isentando-o de erros e omissões remanescentes.

* $\quad$ Mestre em Economia pelo Programa de Pós-Graduação em Ciências Econômicas (PPGCE) da Universidade do Estado do Rio de Janeiro (UERJ). Pesquisador do Centro de Estudos de Estratégias de Desenvolvimento (CEDES) da UERJ. E-mail: rsbassociados@gmail.com

** Professor titular da Faculdade de Ciências Econômicas (FCE) da UERJ. Pesquisador do CNPq. E-mail: luizfpaula@terra.com.br 


\section{1 lntrodução}

Após o período de implementação do Plano Real, as instituições financeiras brasileiras precisaram se reinventar para adquirir novas formas de obter receitas operacionais (BRANCO, 2008). A receita inflacionária tinha participação importante no total auferido pelos bancos, e, após a queda dos níveis de inflação, houve uma forte redução nessa fonte de receita até sua virtual extinção em 1996 (IBGE, 1997). Esses ganhos eram obtidos através da manutenção no passivo dos bancos de saldos em contas correntes não remuneradas, saldos estes que quando aplicados rendiam, basicamente, a correção monetária existente à época, que era elevada devido aos níveis de inflação. Esses ganhos representavam cerca de 38,5\% das receitas bancárias auferidas no último período de inflação elevada, isto é, 19911993 (IBGE, 1997). Com isso, os bancos tiveram a necessidade de recompor suas receitas a partir de alternativas que compensassem tal perda, como a busca pelo aumento de suas carteiras de crédito a fim de incrementar a fonte de receita de intermediação financeira que antes era posta em segundo plano nos objetivos de lucratividade dos bancos.

Nesse contexto, o spread bancário se tornou uma variável do maior interesse para análise no período pós-inflacionário, visto que a concessão de crédito ganharia importância e tornar-se-ia uma das principais formas dos bancos auferirem receitas atualmente. O próprio Banco Central do Brasil (BCB), a partir de 1999, passa a produzir anualmente um relatório sobre a decomposição e o nível do spread bancário no Brasil. Igualmente, a análise no mundo acadêmico teve seu início no Brasil a partir do artigo precursor de Aronovich (1994) e, posteriormente, do artigo de Afainasieff et al. (2002).

O spread bancário pode ser analisado também pelas óticas micro e macroeconômicas. Pelo lado microeconômico, o spread pode ser determinado junto com os demais componentes pertencentes às receitas da firma bancária. Ele passa a ser o resíduo líquido (em inglês, net interest margin - NIM) após a subtração das despesas operacionais, tributárias, custos de inadimplência e com o compulsório, que é o percentual exigido de capital pelo BCB nas operações realizadas pelos bancos. Já sob a ótica macroeconômica, o spread pode ser analisado de acordo com algumas variáveis amplamente conhecidas, como o PIB e as taxas de juros e de inflação, e também através de variáveis discricionárias ligadas ao $\mathrm{BCB}$, como o compulsório bancário. Tais variáveis são analisadas na literatura como determinantes macroeconômicas do spread e exercem papel singular no comportamento deste último na estrutura bancária.

No caso do Brasil, a manutenção da taxa básica de juros da economia em patamares relativamente elevados torna interessante aos bancos aplicarem parte de seus recursos em títulos que a tenham como indexador, o que ocorre com as 
Letras Financeiras do Tesouro Nacional (LFT). Com isso, as instituições financeiras têm uma importante fonte de receita - de baixo risco e alta rentabilidade - disponível para compor e competir com as demais receitas bancárias, como a atividade de intermediação financeira, ou seja, a captação de recursos e a concessão de empréstimos. O custo de oportunidade dos bancos (PAULA; ALVES JR., 2003) se eleva em função da existência de uma aplicação livre de risco (LFT) que combina liquidez e rentabilidade, o que torna elevado o prêmio de risco nas operações de concessão de empréstimos, afetando assim o nível do spread bancário.

Este artigo analisa os possíveis determinantes do spread bancário no Brasil, dando ênfase à contribuição que os títulos públicos atrelados à Selic possam dar à manutenção dos níveis elevados de spread no Brasil, reconhecidamente um dos maiores do mundo. Além desta introdução, o artigo está dividido em mais cinco seções: a seção 2 realiza uma revisão histórica da dívida pública brasileira, a partir do período de inflação elevada, que gerou a necessidade da criação de títulos de dívida atrelados à taxa de juros; a seção 3 mostra um panorama do spread bancário no período pós-implementação do real, de 1995 a 2011; a seção 4 efetua uma revisão da literatura nacional e internacional sobre spread bancário; a seção 5 detalha a metodologia e a base de dados utilizada para aferir a importância dos títulos atrelados à taxa de juros básica da economia nas variações do spread, além de apresentar e interpretar os resultados obtidos com a utilização da metodologia escolhida; e, por fim, a seção 6 trata das considerações finais do artigo.

\section{Títulos Públicos no Brasil: o Papel das LFT}

Desde a criação das obrigações reajustáveis do Tesouro Nacional (ORTN) em 1964, o Estado brasileiro passou a utilizar a emissão de títulos públicos para financiar sua dívida. Como função primordial, um título de dívida pública permite o endividamento por parte do Estado para financiar despesas inerentes da administração pública que não têm, de imediato, contrapartidas necessárias para cobrir seus gastos. Outra função importante dos títulos públicos é a sua utilização por parte do BCB para fazer a "sintonia fina" da liquidez com as operações de mercado aberto.

Com as mudanças estruturais ocorridas na economia brasileira, principalmente após a implantação do Plano Real, ocorreram também alterações substanciais na utilização de ferramentas diferentes na política econômica praticada pelos governos desde então. Com o intuito de atrair capital externo para financiar o déficit em transações correntes (com exceção do período 2004-2007), os governos do período recente utilizaram o diferencial positivo interno da taxa de juros brasileira em relação às taxas internacionais como componente do modelo econômico adotado nas duas últimas décadas, visando à atração de capital externo para o país, tanto na forma de investimentos em portfólio, quanto na forma de investimento 
direto externo (IDE) (LAPLANE; SARTI, 1999). De fato, enquanto no período do Plano Real o diferencial de juros era fundamental para atrair capitais externos no contexto de uma âncora cambial, após a adoção do regime de metas de inflação, em 1999, o afluxo de capitais externos contribuiu para apreciar a taxa de câmbio, fundamental para o BCB lograr êxito na sua política anti-inflacionária (ARESTIS; FERRARI FILHO; PAULA, 2011).

Entretanto, a taxa básica de juros também é utilizada como indexador de um dos principais títulos públicos emitidos pelo governo para a rolagem e contração de novas dívidas. As LFT são títulos que utilizam a Selic como indexador, o que proporciona um efeito ambíguo na economia como um todo. Se, por um lado, há uma maior entrada de capital externo com a compra das LFT, possibilitando o aumento do endividamento quando a Selic sobe, por outro há o crescimento do custo da dívida pública atrelada às LFT, o qual o país tem de arcar. Além disso, a conexão direta existente entre a indexação de títulos públicos à taxa de juros, corrigida diariamente, ocasiona a não existência do prêmio de risco no título, dado que seu cupom é de um dia (BARBOSA, 2006).

Outro ponto relevante é a ligação entre o mercado de títulos públicos e as reservas do $\mathrm{BCB}$. Isso ocorre em virtude da necessidade de utilização das reservas para "esterilizar" a operação com os títulos indexados à Selic (CARDOSO, 2001). Se há excesso de demanda pelos títulos por parte dos agentes, o BCB é obrigado a dar liquidez ao sistema de forma a manter disponível a mesma quantidade de moeda em poder do público, equilibrando a base monetária. Por outro lado, se há excesso de oferta de títulos atrelados à Selic, ou se os agentes possuidores dos títulos optam por vendê-los, o BCB, mais uma vez, terá que utilizar suas reservas na liquidação desses títulos (CARDOSO, 2001).

A justificativa para a criação de títulos públicos que tivessem como indexador a taxa básica de juros da economia foi o período de alta inflação atravessado pelo Brasil nos anos 1980. A criação das LFT veio, então, a reboque da LBC, com a única diferença de ter como emissor o Tesouro Nacional, e não o BCB. Portanto, a criação de títulos indexados à taxa Selic deu-se para atender a necessidade que o período inflacionário impunha à economia brasileira, em função do elevado risco de carregamento dos títulos públicos prefixados no contexto de alta inflação, com seus efeitos nocivos relativos à dívida pública. Após a introdução do Plano Real, a inflação arrefeceu para níveis em que não é mais interessante a manutenção de parte significativa da dívida indexada à taxa de juros estipulada periodicamente pelo Comitê de Política Monetária (Copom). Atualmente, tais títulos geram efeitos negativos importantes na economia brasileira, uma vez que inibem a constituição 
de uma curva de rendimentos de longo prazo adequada à emissão de títulos privados, acarretando uma piora no canal de transmissão da política monetária ao gerar um efeito riqueza invertido, uma vez que parte da riqueza financeira está atrelada à própria Selic.

\subsection{Emissão de LFT no Período Recente}

A emissão das LFT nos últimos anos sofreu grandes variações nos volumes subscritos como parte da dívida pública brasileira. Com dados disponíveis do Tesouro Nacional desde 2000, observa-se que houve uma forte expansão da emissão até 2002, para uma sensível redução desde então. Em 2000, o montante de LFT emitidas alcançou $\mathrm{R} \$ 152,5$ bilhões, tendo subido para $\mathrm{R} \$ 177,0$ bilhões já no ano seguinte.

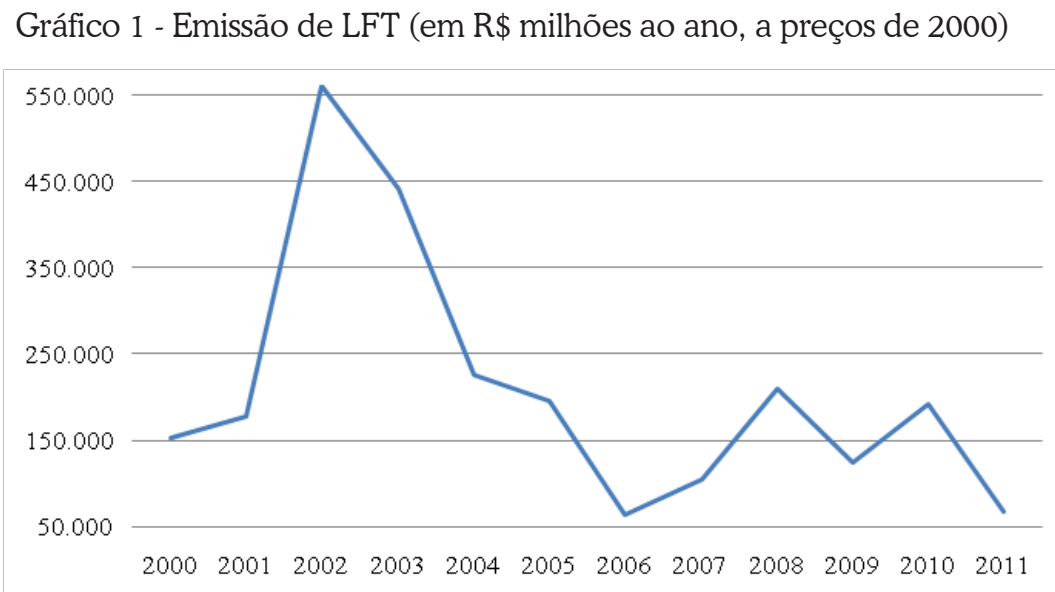

Fonte: Elaboração própria a partir de dados de Brasil (2012).

A participação dos títulos indexados à Selic em relação ao total da dívida pública brasileira desde 1995 tem variado de forma significativa. Em 1995, início do período de estabilização da economia brasileira, a participação cresce de 14,6\% para 41,1\% já em agosto do mesmo ano. Após isso, a taxa de participação da dívida indexada à taxa de juros básica cai para 20,1\% em maio de 1996, sendo trocada por dívida prefixada de curto prazo (maturidade menor que um ano). Em meados de 1997, as trajetórias da dívida atrelada à Selic e da própria taxa básica de juros apresentam volatilidades significativas. Esse período tem seu final em junho de 1999, como podemos observar no Gráfico 2, e se justifica por causa das crises internacionais ocorridas na Ásia, em 1997, e na Rússia, em 1998. Como o Brasil precisava manter sua taxa de câmbio inalterada - dado o esquema de âncora 
cambial -, a ferramenta de política macroeconômica utilizada diante de tais crises foi a de política monetária, através da alteração da taxa básica de juros, uma taxa estratosférica em períodos de contágios (FERRARI FILHO; PAULA, 2003). Esse período teve fim com a desvalorização do real frente ao dólar, em 1999. A partir de meados de 2002 até início de 2003, a participação das LFT no total da dívida pública pulou de $50 \%$ para $60 \%$, acompanhando a elevação na taxa de juros e o momento de instabilidade macroeconômica. A participação de títulos públicos indexados à Selic no total da dívida pública federal foi de mais de 50\% de meados de 1988 ao início de 2006, quando tal participação passou a diminuir gradualmente, caindo para menos de $30 \%$ a partir de meados de 2007 , acompanhando a queda na taxa de juros e a maior estabilidade macroeconômica do país.

Gráfico 2 - Percentual da dívida pública atrelada à Selic e taxa Selic (\% a.m.)

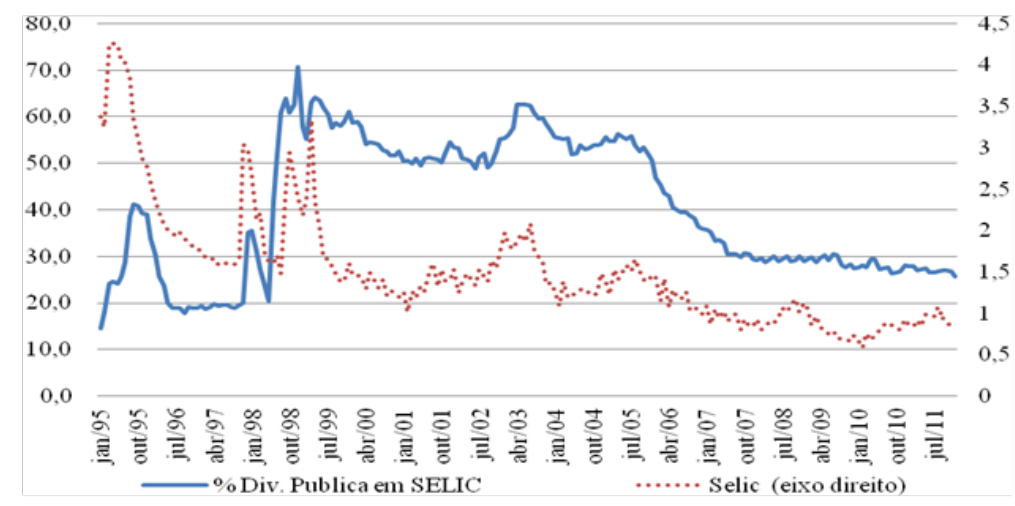

Fonte: Elaboração própria a partir de dados do Banco Central do Brasil (2012).

\section{Panorama e Evolução do Spread Bancário Brasileiro entre 1995 e 2011}

No período que se inicia após a implementação do Plano Real, o spread bancário mantinha ainda níveis semelhantes aos observados antes da introdução do plano. Em 1995, as taxas de spread total, pessoa física e pessoa jurídica oscilavam em torno de 137, 171 e 103 pontos percentuais ao ano, respectivamente. A memória das receitas inflacionárias ainda era um resquício do cenário macroeconômico de altas crônicas nos preços. Entretanto, já em 1996, há uma queda vertiginosa nos spreads, fechando o ano em torno de 50 pontos percentuais menor que no anterior. Há uma elevação entre meados de 1997 até o início de 1999, quando houve a alteração no regime cambial para câmbio flutuante. Na sequência, ocorreram novas quedas, porém de menor magnitude do que a observada em 1996. Mais recentemente, em 2008, observa-se novamente uma relativa alta nos spreads, tanto 
no total quanto para pessoas físicas e jurídicas, grande parte em virtude da crise financeira internacional surgida nos Estados Unidos. Os spreads, posteriormente, voltaram a cair em 2009 e se mantêm em patamares acima dos 30 pontos percentuais por ano. ${ }^{1} \mathrm{O}$ Gráfico 3 ilustra a trajetória completa.

\section{Gráfico 3 - Spread médio com recursos livres (em pontos percentuais acumulados em 12 meses)}

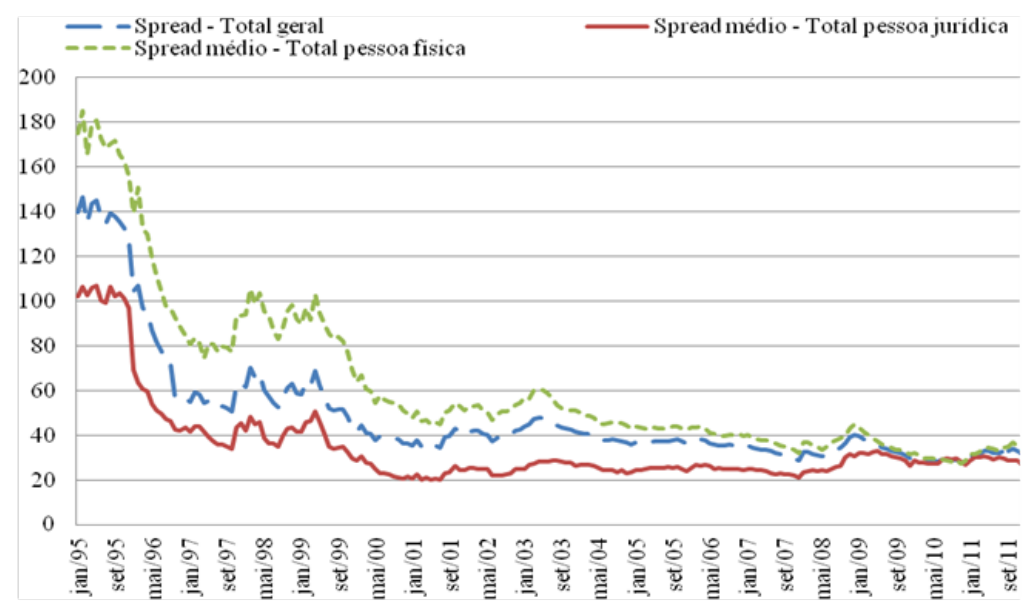

Fonte: Banco Central do Brasil (2012).

A partir de 2009, há certa estabilidade na evolução das taxas de spread, tanto na rubrica de pessoa física quanto na de pessoa jurídica. As medidas de estímulo ao crédito no pós-crise de 2008 adotadas pelo governo brasileiro podem explicar, em parte, essa diminuição. No entanto, já no final de 2010, a disparidade entre spread pessoa física e jurídica volta a aumentar, porém em patamares sensivelmente inferiores aos observados em meados dos anos 1990, após a adoção do real. Essa nova disparidade entre as taxas indica uma conexão maior com variáveis endógenas de impacto para as instituições financeiras - como os diferentes níveis de inadimplência - do que no período anterior, quando prevaleciam os efeitos das alterações macroeconômicas.

1 Reis Júnior, Paula e Leal (2013), ao analisarem a evolução e a estrutura do spread bancário por segmento de capital no período 2000-2008 no Brasil, concluem que, considerando o grupo de "grandes bancos varejistas" - públicos, estrangeiros e privados nacionais -, observa-se que o subsegmento dos bancos estrangeiros apresentou spreads mais elevados em relação aos outros segmentos, sendo que em particular o spread menor tem sido o dos bancos públicos. 


\subsection{Relação entre Spread e Taxa Selic}

O cenário macroeconômico instável observado no Brasil até a implementação do Plano Real foi utilizado como justificativa para os altos níveis do spread bancário brasileiro. Como já dito anteriormente, as altas taxas de inflação inibiam as instituições financeiras nacionais de conceder empréstimos porque os bancos obtinham receitas através de outras fontes, como as aplicações realizadas com títulos overnight (LOPES, 1997). Além disso, devido à imprevisibilidade das taxas de inflação, o prêmio de risco embutido nas taxas de empréstimos era muito elevado. Contudo, tal cenário sofreu mudanças estruturais após a implementação do Plano Real, com a significativa redução da inflação, que proporcionou a redução dos níveis de spread praticados pelos bancos nos primeiros anos do pós-Real. Porém, após isso, as variações no spread bancário passaram a acompanhar a evolução de variáveis macroeconômicas que ganharam importância após o período de estabilização, como é o caso da taxa básica de juros, que, como visto, manteve-se em patamares elevadíssimos (ver Gráfico 4). Segundo diversos trabalhos realizados sobre o spread bancário no Brasil (SILVA; OREIRO; PAULA, 2007; PAULA; PIRES, 2007; NAKANE, 2003), a Selic é uma das variáveis macroeconômicas que apresenta maior significância entre as que compõem o spread bancário. Nela estão refletidas as operações de crédito do mercado interbancário brasileiro, que dão base às demais operações de crédito na economia. Ademais, a taxa básica de juros ganha importância no cenário econômico brasileiro após o início do período de estabilização, uma vez que passa a ser efetivamente um instrumento de política monetária com a finalidade de controlar os níveis de inflação, sendo esse papel mais explícito a partir da implementação do regime de metas da inflação a partir de meados de 1999.

Gráfico 4 - Spread total e Selic (\% a.m.)

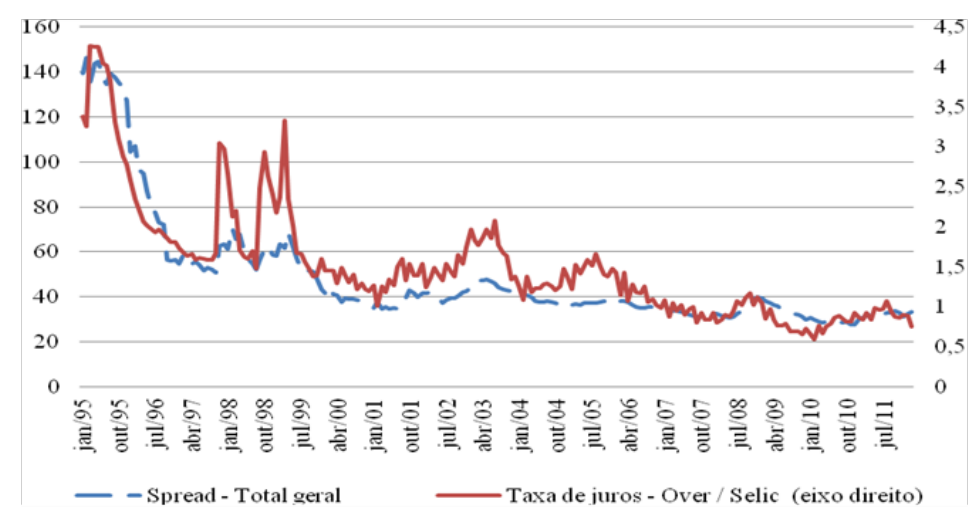

Fonte: Elaboração própria a partir de Banco Central (2012). 
A queda do spread após o fim do período de alta inflação acompanha a redução na taxa básica de juros até meados de 1997. Contudo, após esse período inicial, observa-se que até junho de 1999 ocorreu uma alta significativa das taxas de juros que não é acompanhada pelo spread. Essa alta ocorre em virtude da crise russa de 1998 (AVERBUG; GIAMBIAGI, 2000), quando foi necessário o aumento na taxa Selic para amenizar a fuga de capitais e, posteriormente, a mudança do regime cambial. Após 1999, as evoluções de spread e da Selic voltam a registrar caminhos semelhantes. Em resumo, a trajetória percorrida pela taxa de spread ao longo dos primeiros anos após a implementação do Plano Real registrou quedas consistentes logo após a mudança no cenário econômico - que passou a ser de baixa inflação -, mas não alcançou novas quedas desde então e se mantém ao redor de $30 \%$ a.a. há mais de uma década. A resiliência dos patamares dos spreads no Brasil em suas diversas modalidades não encontra explicação suficiente que possa indicar a diferença entre as taxas praticadas no Brasil e as dos demais países.

\section{Literatura sobre Spread Bancário}

\subsection{Literatura Internacional}

Há uma vasta literatura internacional sobre o tema spread bancário e, em menor quantidade, artigos nacionais no período recente. ${ }^{2} \mathrm{O}$ artigo seminal sobre os determinantes do spread bancário é o de Ho e Saunders (1981), que analisa o spread dos 100 maiores bancos americanos em 13 trimestres (de 1976 a 1979), considerando o banco como um dealer (intermediário financeiro) no mercado de crédito, avesso ao risco e, portanto, os autores consideram o banco como uma firma comum. Por ser um intermediário entre depositantes e tomadores, o banco está sujeito a dois tipos de risco: o risco gerado pelo descasamento que pode ocorrer entre o volume e diferentes períodos em que depósitos e empréstimos são feitos; e o risco na taxa de retorno dos empréstimos, pois poderá haver tomadores que não honrem suas dívidas (inadimplência), o que gera a probabilidade de default do banco, pois essa probabilidade não é conhecida ex ante a concessão de crédito. O modelo econométrico estimado pelos autores é desenvolvido pelo método de mínimos quadrados ordinários $(\mathrm{MQO})$ em dois estágios, inferindo que a utilidade esperada da riqueza auferida pelos bancos no fim do período representaria o spread. Como resultado da pesquisa empírica, o modelo de regressão no primeiro estágio mostra que o valor do intercepto - considerado como o spread puro

2 Nessa breve resenha se privilegia os trabalhos que avaliaram empiricamente os determinantes do nível do spread bancário, utilizando-se o método de dois estágios desenvolvido originalmente por Ho e Saunders (1981), já que há vários estudos que tratam da estrutura e decomposição do spread. Para uma resenha mais completa da literatura internacional sobre spread bancário, ver Leal e Paula (2011).

BRANCO, R. S.; PAULA, L. F. O Impacto da Dívida Pública sobre o Spread Bancário... 
- é significante e positivo em relação à variável explicada e também é em relação à variável de pagamento implícito de juros. No segundo estágio da regressão, com as variáveis macroeconômicas, mostra-se significativa a variável de volatilidade da taxa de juros (sinal positivo), ou seja, quanto maior a variação da taxa de juros básica da economia, maior será o spread.

Saunders e Schumacher (2000) analisam os determinantes da margem líquida dos bancos em seis países europeus e nos Estados Unidos no período de 1988 a 1995, com uma amostra de 615 bancos. Os autores decompõem a margem líquida de intermediação (net interest margins - NIM) em um componente regulatório, um de estrutura de mercado e outro de prêmio de risco. O modelo utilizado baseia-se em Ho e Saunders (1981), considerando os bancos como agentes intermediadores avessos ao risco e utilizando o método de $\mathrm{MQO}$ em dois estágios. Os resultados encontrados indicam que, das três variáveis de controle escolhidas (volatilidade da taxa de juros, aversão ao risco e tamanho do empréstimo e despesa implícita com juros), a taxa implícita de juros foi a de maior efeito (positivo) em relação à variável dependente, ou seja, a margem líquida; os custos de reserva de capital apresentaram o resultado esperado (positivo); e a taxa de ativos de capital dos bancos também apresentou relação positiva com as margens líquidas dos bancos, ou spreads. O spread puro, que é obtido como intercepto da regressão no primeiro estágio, explicou $62 \%$ do spread total quando comparado com as demais variáveis de controle. Em resumo, os resultados encontrados apontam para um importante trade-off entre solvência das instituições bancárias - grandes taxas de ativos de capital - contra a redução dos custos financeiros. Além disso, conclui também que quanto maior o poder de monopólio das instituições, tanto geograficamente quanto por segmento, maiores as margens de spread cobradas.

Brock e Rojas Suarez (2000) analisam diferentes medidas do spread ex post e seu comportamento para Argentina, Bolívia, Chile, Colômbia, México e Peru, com dados contábeis de uma amostra de bancos entre 1991 e 1996. O escopo dos autores é investigar o motivo da não redução do spread bancário nesses países da América Latina, num período de aprofundamento financeiro resultante da reforma do setor, caracterizado pela redução dos requerimentos de reservas e das restrições diretas ao crédito e às taxas de juros. Os autores utilizam o modelo de Ho e Saunders (1981) com regressão em painel de dois estágios para estimar os determinantes do spread para cada um dos países individualmente, exceto o México. Os resultados do primeiro estágio indicam que alguns dos países investigados no trabalho apresentam relação positiva e significativa entre o spread e as seguintes variáveis: relação capital-ativo (Bolívia e Colômbia), custo (Argentina e Bolívia) e liquidez (Bolívia, Colômbia e Peru). Por outro lado, o risco de inadimplência não correspondeu à expectativa de relação positiva com o spread bancário (exceto para a Colômbia). Os autores associam esse resultado à inadequada provisão para 
perdas nos empréstimos e às estratégias de crescimento de alto risco dos bancos. Quanto às variáveis macroeconômicas, no segundo estágio Brock e Rojas Suarez (2000) observam que, para a maioria dos países, a incerteza macroeconômica, representada pela volatilidade de juros (Bolívia e Chile) e pela inflação (Colômbia, Chile e Peru), apresenta relação positiva com o spread, corroborando os resultados de estudos para os países desenvolvidos (SAUNDERS; SCHUMACHER, 2000).

Posteriormente, Maudos e Guevara (2004) também analisam o setor bancário europeu considerando um total de cinco países (Alemanha, França, Reino Unido, Itália e Espanha), no período de 1993 a 2000, utilizando o modelo de Ho e Saunders com ajustes e levando em conta uma estrutura de custos operacionais. Diferentemente de outros trabalhos, o artigo considera o índice de Lerner como medida do grau de competição nos diversos mercados bancários analisados na Europa. O resultado mais geral encontrado contraria a maior parte dos artigos sobre o tema, revelando que a concentração bancária recente no setor nos países estudados levou a uma redução nas margens dos bancos. Um indício que deve ser levado em conta, dado o resultado contrário esperado, é que a amostra de países europeus escolhidos já tem o setor bancário consolidado e com margens líquidas menores quando comparadas às demais economias europeias (novos países participantes e pretendentes da entrada na União Europeia), o que vai de encontro com os demais artigos do tema.

Fungacova e Pohosyan (2011) analisam os determinantes da margem líquida de intermediação no setor bancário russo utilizando um conjunto de dados trimestrais do balanço dos bancos no setor bancário da Rússia no período 19992007. A metodologia utilizada é a do modelo de Ho e Saunders (1981), dividindo a amostra por estrutura de capital para examinar as variações nos determinantes da margem líquida de juros (NIM). São utilizados dados em painel com um estimador de efeitos fixos e regressões separadas para diferentes estruturas de capital. A variável dependente é o NIM (receita de juros menos despesas de juros divididos pelo total de ativos); as variáveis independentes são o índice Herfindahl regional, despesas pessoais sobre total de ativos, capitalização (razão patrimônio líquido sobre total de ativos), razão empréstimos em atraso sobre total de ativos, tamanho do banco (logaritmo do total de ativos) e razão de liquidez (ativos líquidos sobre depósitos a vista). No modelo básico desenvolvido, todos os coeficientes estimados, com exceção do Índice de Herfindahl-Hirschman (IHH), foram significativos, o NIM não é afetado por mudanças da estrutura de mercado, os custos operacionais são transmitidos aos clientes através de maiores margens cobradas sobre serviços, o coeficiente positivo significativo da razão de capitalização indica que bancos com maior aversão ao risco tendem a cobrarem maiores margens, o tamanho das operações confirma a presença de economias de escala (maiores bancos tendem a 
terem margens menores), o risco de liquidez é significativo e negativo e, por fim, o risco de crédito tem coeficiente negativo, o que contradiz os achados da literatura.

\subsection{Literatura Nacional}

Afanaisieff et al (2002) investigam o spread bancário no Brasil através dos efeitos micro e macroeconômicos utilizando o modelo de Ho e Saunders com dados em painel no período de 1997 a 2000 para 147 bancos brasileiros. As variáveis utilizadas no primeiro estágio da regressão foram o número de empregados das instituições, custos operacionais, razão de depósitos totais sobre o ativo, razão de fundos remunerados sobre ativos, alavancagem e liquidez bancária. Não foram encontrados resultados significantes para essas variáveis no primeiro estágio da regressão. Já no segundo estágio, o spread puro (intercepto da regressão anterior) foi regredido em conjunto com a volatilidade da taxa de juros de mercado, o PIB e a inflação. Os resultados apresentados foram significantes em todas as variáveis, excetuando-se a de crescimento do PIB. Como conclusão, o artigo indica a importância da dispersão que o spread tem entre os bancos no Brasil, o que pode levar a uma perda de importância das variáveis macroeconômicas nos testes econométricos - e na economia - e a um menor efeito das políticas monetárias, como alteração na taxa básica de juros, em relação às variações do spread.

Nakane (2003) analisa a competitividade no setor bancário brasileiro, procurando justificativas para os índices elevados de spread no país. Numa primeira etapa, o autor utiliza o Índice de Herfindahl observado no período de 1994 a 2003 dos bancos brasileiros e compara os resultados com o mesmo índice em outros países. A conclusão dessa primeira etapa relata que o setor bancário brasileiro pertence ao grupo de países onde há competição perfeita em alguns anos da amostra e competição imperfeita nos demais anos do período analisado, caracterizando a não participação do setor brasileiro como um cartel, oligopólio ou outro modelo não competitivo. Na segunda parte do estudo, o autor adota uma metodologia microeconômica desenvolvida por Bresnahan (1982) e Lau (1982) que utiliza uma estrutura de mercado como a de um cartel, com as variáveis demanda inicial, receita marginal e funções de custo marginal lineares. $\mathrm{O}$ teste conclui que os bancos brasileiros possuem algum poder de mercado, mas descarta a existência de estruturas competitivas extremas (concorrência perfeita e cartel), e ainda sugere que a concorrência no setor é elevada. Pode-se concluir, portanto, através desses resultados, que os spreads elevados não seriam fruto de uma estrutura de mercado que favorecesse os bancos brasileiros, pois os resultados encontrados não caracterizam qualquer forma de cartel/conluio.

Silva, Oreiro e Paula (2007) utilizam o modelo de vetores autorregressivos (VAR) para testar a importâncias das variáveis macroeconômicas no spread ban- 
cário brasileiro. O período da amostra vai de 1997 a 2001, tendo como variáveis dependentes no modelo a volatilidade de juros, o nível de atividade econômica, a incerteza no ambiente econômico e a inflação. Os resultados corroboram o estudo de Afanaisieff (2002), tendo como impactos significantes no spread as variáveis inflação e taxa de juros como determinantes macroeconômicos.

Paula e Pires (2007), por sua vez, calculam a relação entre variáveis macroeconômicas e o spread para um conjunto de 18 países entre 1998 e 2004, com dados trimestrais. O modelo proposto utiliza dados em painel estático e dinâmico com efeitos fixos, relacionando as variáveis macroeconômicas - taxa básica de juros, taxa de desemprego e inflação. Os resultados do trabalho indicam uma relação positiva entre o spread e sua própria defasagem, e ainda entre spread e taxa de juros, e spread e inflação. O desemprego, por sua vez, não foi significativo no exercício econométrico.

O trabalho de Manhiça e Jorge (2012) diferencia as medições feitas para o spread no Brasil através dos conceitos de ex ante e ex post, bem como a relação entre os fatores que podem afetar o comportamento da variável no período de 2000 a 2008: o aspecto jurídico, o qual exige características específicas do spread no Brasil; a estrutura de mercado, relativa aos fatores microeconômicos que influenciam o spread a partir da visão interna das instituições financeiras brasileiras; e o aspecto macroeconômico, que se mostra fundamental para o entendimento do compor-

tamento das margens de lucro dos bancos. É realizado o exercício econométrico também no formato de duas etapas, sendo a primeira para indicar os efeitos microeconômicos e a segunda etapa para os efeitos macroeconômicos. Como resultado, a taxa de juros básica da economia, bem como sua volatilidade se mostram relevantes para explicar o spread, além do tamanho da instituição financeira.

\section{Metodologia, Base de Dados e Resultados Obtidos}

\subsection{Metodologia}

A metodologia utilizada neste trabalho se baseia em Ho e Saunders (1981), com a atualização realizada por Brock e Rojas Suarez (2000) e Maudos e Guevara (2004). Nela, o banco é visto como um intermediário financeiro - dealer - avesso ao risco, e tem como variáveis principais no modelo as variâncias de risco de capital e de juros, que indicam a disposição do banco em realizar novas operações.

O modelo econométrico a ser utilizado é o mesmo adotado pela referida literatura, qual seja, mínimos quadrados em dois estágios (MQ2E). O método favorece a separação de efeitos distintos em dois grupos de variáveis - no caso, as microeconômicas e as macroeconômicas - através da elaboração de duas equações separadas nas etapas de cálculo propostas. O modelo em dois estágios tem a vantagem de permitir a estimação do spread puro a partir das variáveis explanatórias 
utilizadas na primeira etapa e analisar a relação entre o spread puro e as variáveis postuladas em uma segunda etapa (MAUDOS; GUEVARA, 2004).

Johnston e Dinardo (1997), por sua vez, ressaltam que as estimativas encontradas na regressão da primeira etapa servem como variáveis instrumentais para a regressão na segunda etapa. Não obstante, Greene (2003) relata que tal metodologia em dois estágios permite replicar a parte não explicada em uma primeira regressão de $\mathrm{MQO}$ simples em uma segunda etapa. ${ }^{3}$

Em uma primeira etapa, utilizam-se variáveis construídas a partir dos dados dos balanços patrimoniais fornecidos pelo Banco Central do Brasil das principais instituições financeiras brasileiras no período 2001-2011. Essas variáveis serão denominadas "microeconômicas" por exibirem o comportamento da firma bancária, excluídos os efeitos exógenos causados pelo cenário econômico externo nos quais os bancos estão inseridos. O objetivo dessa etapa inicial é captar os efeitos das variáveis microeconômicas sobre o spread bruto. Tendo o spread bruto como a variável dependente na primeira etapa, a regressão é realizada a partir das variáveis independentes que afetariam os bancos individualmente - as variáveis microeconômicas, que serão detalhadas na próxima seção. São utilizados, na primeira etapa de cálculo, dados em cross-section, gerando uma equação para cada período de tempo da amostra analisada. As estimativas obtidas nesse primeiro estágio de cálculo são utilizadas na segunda etapa a partir dos interceptos e resíduos gerados em cada regressão. Os interceptos gerados são denominados de "spread puro", dado que foram retirados os efeitos microeconômicos. Já os resíduos exibidos são interpretados pela literatura como uma proxy para a volatilidade das taxas de intermediação realizadas pelas instituições financeiras.

O spread puro é, então, utilizado como variável dependente na segunda etapa e é regredido com as variáveis exógenas ligadas ao cenário macroeconômico brasileiro. Inflação, Selic e volatilidade são algumas das variáveis macroeconômicas que podem demonstrar os possíveis efeitos de medidas macroeconômicas adotadas e que possam, por ventura, afetar o spread dos bancos. A hipótese é que tais variáveis sejam significativas para explicar o spread bancário de forma mais acurada, após a exclusão dos efeitos das variáveis microeconômicas.

O formato matemático das equações referentes ao modelo utilizado se apresenta da seguinte forma:

$$
S=\beta_{0}+\sum \beta_{i} X_{i}+e
$$

3 Contudo, como assinala Wooldridge (2002, p. 479), a utilização do MQ2E pode gerar um problema de multicolinearidade maior do que no MQO simples, além de ser uma estimação menos eficiente do que o MQO quando as variáveis explicativas forem exógenas. Entretanto, o teste utilizado para medir a multicolinearidade no modelo proposto neste trabalho não foi significante. Tal fato pode decorrer da interação conjunta das variáveis na regressão realizada. 
Essa primeira equação seria o formato matemático para cada uma das regressões geradas no primeiro estágio de cálculo. Como já dito, o $\beta_{0}$ e o resíduo e serão utilizados na segunda etapa, conforme descrito a seguir:

$$
\beta_{0}=\delta_{0}+\sum \delta_{i} Y_{i}+\varepsilon
$$

Na próxima seção, detalhar-se-á a construção e denominação dos dois grupos distintos de variáveis independentes a serem utilizadas nas distintas etapas de cálculo.

\subsubsection{Variáveis Microeconômicas}

O spread bruto, variável dependente da regressão, é estimado pela razão entre as rubricas denominadas "resultado bruto" e "ativo total", ambas fornecidas pelo BCB. As variáveis microeconômicas a serem regredidas na primeira etapa de cálculo do modelo como variáveis independentes em relação ao spread bruto (resultado bruto) são construídas nas formas descritas a seguir:

$$
\begin{gathered}
\text { Custo }=\frac{\text { Custo Operacional }}{\text { Ativo Total }} \\
\mathrm{IHH}=\sum \mathrm{s}^{2}
\end{gathered}
$$

em que s é o market-share individual dos bancos;

$$
\begin{aligned}
& \text { Provisão }=\frac{\text { Provisão CL }}{\text { Ativo Total }} \\
& \text { Aversão }=\frac{\text { Ativo Total }}{\text { Patrimônio Líquido }}
\end{aligned}
$$

essas variáveis serão inseridas na equação de regressão da seguinte forma:.

$$
\text { Spread bruto }=\beta_{0}+\beta_{1} \text { custo }+\beta_{2} \mathrm{IHH}+\beta_{3} \text { prov }+\beta_{4} \text { aver }+e
$$


em que custo é o custo operacional, $\mathrm{IHH}$ refere-se ao índice de Herfindahl, ${ }^{4}$ prov é a variável provisão para clientes duvidosos ${ }^{5}$ e aver corresponde à variável para aversão ao risco, além do e, que pretende captar o que não está explicado nessa primeira etapa. Tais variáveis foram construídas conforme a metodologia utilizada em Maudos e Guevara (2004) e pretendem explicar como os fatores intrínsecos a cada firma bancária afetam o nível do spread bancário.

Após a exposição de como a primeira equação de regressão será elaborada, vale deduzir quais serão os sinais esperados para cada uma das variáveis a fim de se interpretar os futuros resultados, conforme detalhado no Quadro 1.

A execução dessa primeira etapa se dará na forma de dados em cross-section, a fim de captar o efeito das variáveis supracitadas a partir de uma amostra dos bancos brasileiros.

Quadro 1 - Justificativas para o comportamento das variáveis microeconômicas

\begin{tabular}{|c|c|l|}
\hline Variável & Sinal esperado & \multicolumn{1}{c|}{ Justificativa } \\
\hline Custo & $(+)$ & $\begin{array}{l}\text { Quanto maior o custo, maior deverá ser o } \\
\text { spread necessário ao funcionamento da firma } \\
\text { bancária. } \\
\text { IHH }\end{array}$ \\
Provisão & $(+)$ & $\begin{array}{l}\text { A maior concentração de mercado permitiria } \\
\text { práticas monopolistas de maiores spreads. } \\
\text { Quanto maior o capital disponibilizado para } \\
\text { a provisão de créditos inadimplentes, maior o } \\
\text { spread em função do aumento de tais despesas } \\
\text { financeiras. } \\
\text { Quanto mais avessa ao risco for a instituição } \\
\text { bancária, maior deverá ser o spread, em função } \\
\text { do prêmio de risco maior embutido nas taxas de } \\
\text { empréstimos. }\end{array}$ \\
\hline
\end{tabular}

Fonte: Elaboração própria.

\subsubsection{Variáveis Macroeconômicas}

Na segunda etapa, pretende-se obter os efeitos do cenário macroeconômico no spread bancário. Para tanto, o spread puro será regredido com as variáveis independentes "Selic", "Ipca", "volatilidade", "receita de valores mobiliários" e "LFT no mercado”. As primeiras variáveis, Selic e Ipca, são os índices amplamente

$4 \quad$ O Índice de Herfindahl-Hirschman é um índice para aferir a concentração de mercado de empresas.

5 A provisão para clientes duvidosos é o valor que as instituições bancárias utilizam para cobrir empréstimos não pagos. 
divulgados pelo $\mathrm{BCB}$ e pelo IBGE, respectivamente. A volatilidade é a variância da taxa de juros no período, enquanto que receita de valores mobiliários e LFT no mercado são as variáveis que tentarão explicar a influência da parcela da dívida pública atrelada à Selic, a partir das LFT, no spread bancário brasileiro. Essas duas últimas são coletadas a partir de informações disponibilizadas também pelo BCB. Os sinais esperados e o comportamento de cada variável estão resumidos no Quadro 2.

Quadro 2 - Justificativas para os comportamentos das variáveis macroeconômicas

\begin{tabular}{|c|c|c|}
\hline Variável & Sinal esperado & Justificativa \\
\hline Selic & $(+)$ & $\begin{array}{l}\text { Quanto maior a Selic, maior o custo de } \\
\text { oportunidade do banco para emprestar } \\
\text { (face a concorrência de títulos "selicados") } \\
\text { e maior o spread em função do maior } \\
\text { prêmio de risco. }\end{array}$ \\
\hline Ipca & $(+)$ & $\begin{array}{l}\text { A inflação gera a necessidade de proteção } \\
\text { por parte dos bancos da perda de valor } \\
\text { nas operações de crédito, o que elevaria o } \\
\text { spread em um cenário de alta na inflação. }\end{array}$ \\
\hline Volatilidade & $(+)$ & $\begin{array}{l}\text { Havendo maior variância da taxa de } \\
\text { juros, aumenta o risco de taxas de juros e } \\
\text { o spread tende a ser também maior para } \\
\text { proteger as instituições das alterações do } \\
\text { cenário macroeconômico. }\end{array}$ \\
\hline $\begin{array}{c}\text { Receita } \\
\text { de valores } \\
\text { mobiliários }\end{array}$ & $(+)$ & $\begin{array}{l}\text { O maior ganho com títulos públicos tende } \\
\text { a inibir a concessão de crédito (volume), } \\
\text { elevando assim o spread para novos em- } \\
\text { préstimos. }\end{array}$ \\
\hline $\begin{array}{l}\text { LFT no mer- } \\
\text { cado }\end{array}$ & $(-)$ & $\begin{array}{l}\text { A maior emissão de LFT por parte do } \\
\text { governo indica um cenário de menor taxa } \\
\text { de juros para a rolagem da dívida pública, } \\
\text { o que contrasta com o comportamento do } \\
\text { spread. }\end{array}$ \\
\hline
\end{tabular}

Fonte: Elaboração própria.

A inclusão de variáveis relativas ao cenário de dívida pública brasileira em um modelo para explicar o spread ainda não foi realizada em trabalhos anteriores sobre o tema. O objeto dessa inovação é captar o efeito deletério que títulos públicos atrelados diretamente à Selic possam ter sobre o comportamento altista do spread bancário. Conforme visto na introdução deste trabalho, a emissão de títulos de dívida indexados à taxa Selic eximem o investidor de risco e torna medidas de 
política monetária menos eficientes (OREIRO; AMARAL, 2008; BARBOSA, 2006). Não obstante, há um elevado nível de dificuldade para a criação de variáveis que captem o efeito da dívida pública brasileira no spread. Isso se dá em virtude da não disponibilização de informações precisas sobre quanto os bancos brasileiros auferem de receitas com títulos especificamente atrelados à Selic.

Por outro lado, por parte do governo, a emissão de dívida pública através de títulos atrelados à Selic deveria ser feita em uma situação "ideal", em que o cenário da taxa básica de juros da economia tivesse viés de baixa e tendência de queda no longo prazo. Ou seja, o maior volume de emissões de títulos "selicados" por parte do Tesouro Nacional deveria ocorrer em trajetória inversa à da taxa Selic. Nesse sentido, essa variável procura explicar o "comportamento" que o Tesouro/governo deveria ter para ofertar novos títulos tendo como indexador a Selic. Daí a relação inversa em relação à da demanda pelos títulos. Surge, então, a necessidade da criação de duas variáveis relacionadas à dívida pública indexada à Selic.

A variável receita de valores mobiliários é o valor financeiro obtido pelos bancos na compra e venda de títulos públicos e privados, que seria uma proxy para o comportamento dos bancos diante da maior ou menor compra e venda de títulos "selicados", as LFT. Inversamente, a variável LFT no mercado procura captar o comportamento do governo a partir da emissão e colocação em mercado de títulos atrelados à Selic.

No entanto, a necessidade do governo em emitir LFT ocorre em períodos de maior instabilidade macroeconômica, como nas crises econômicas externas ocorridas entre 1997 e 2003, com o intuito de atender a demanda por hedge de risco de taxa de juros por parte dos investidores privados. Com a utilização de títulos públicos atrelados diretamente à taxa de juros Selic, o pagamento do prêmio de risco é menor do que seria necessário caso fossem emitidos títulos prefixados, em condições de forte aversão ao risco por parte dos investidores.

Assim, temos uma taxa de juros menor do que seria a prevalecente com títulos prefixados ainda que a contraparte do risco de taxa de juros fique nas mãos do governo, gerando um elevado custo fiscal na rolagem da dívida pública. O formato da equação de regressão dessa segunda etapa é, portanto

$$
\text { Spread puro }=\beta_{0}+\beta_{1} \text { Selic }+\beta_{2} \text { Ipca }+\beta_{3} \text { Receita Val.Mob. }+\beta_{4} \text { Volatil. }+\beta_{5} L F T+
$$

em que, o spread puro é a variável dependente e proveniente da primeira etapa de cálculo, como já explicado anteriormente; Selic e Ipca são a taxa básica de juros da economia brasileira e o índice de inflação, respectivamente; receita Val. Mob. são as receitas obtidas pelos bancos através da aplicação em títulos; e LFT é o valor financeiro de títulos dessa natureza em poder dos agentes econômicos, excluídos os governamentais. 


\subsection{Base de Dados}

A base de dados abrange o período entre os anos de 2001 e 2011, com periodicidade trimestral, tendo, portanto, 44 observações. Foram coletados dados, em média, dos 140 maiores bancos brasileiros a cada trimestre, classificados pelo tamanho do ativo total individualmente. Portanto, nessa primeira etapa com dados em cross-section, são 6.160 observações cruzadas entre os dados disponíveis. Esses dados foram coletados através do site do $\mathrm{BCB}$, de acordo com as rubricas e nomenclaturas geradas para os dados patrimoniais de cada instituição, bem como do IBGE para a série de IPCA. Na segunda etapa, utilizamos séries temporais com 44 observações individuais para cada variável. Todos os testes econométricos realizados neste trabalho foram executados pelo software Gretl 1.9.

\subsection{Resultados}

Dentre as variáveis com maior significância, o custo foi a que obteve maior grau de significância, a níveis acima de $95 \%$, e apresentou o sinal positivo esperado em relação ao spread. A constante gerada na primeira etapa também foi significante nos subperíodos, com sinal positivo, além de representar grande participação no spread bruto. Isso indica a importância dos demais fatores na explicação do spread bancário no Brasil no período recente. A variável aversão foi positiva e significante na maioria dos períodos analisados, acima de $90 \%$. Já a variável provisão exibiu comportamento instável, com significância na maior parte dos trimestres e sinal positivo. O índice de concentração bancária IHH não mostrou significância no modelo e não exibiu o sinal esperado.

A Tabela 1 exibe os resultados para trimestres selecionados. ${ }^{6}$ Os valores em negrito são os que exibiram significância de ao menos $90 \%$, e os números entre parênteses são as estatísticas $t$ para cada uma das estimativas.

$6 \quad$ Os resultados completos das regressões realizadas da primeira e da segunda etapas podem ser solicitados aos autores deste artigo. 
Tabela 1 - Resultados da primeira etapa para trimestres selecionados

\begin{tabular}{rrrrrr}
\hline Período & $\begin{array}{c}\text { Constante } \\
\text { (spread puro) }\end{array}$ & \multicolumn{1}{c}{ Custo } & \multicolumn{1}{c}{ IHH } & \multicolumn{1}{c}{ Provisão } & \multicolumn{1}{c}{ Aversão } \\
\hline 2001.1 & 0,00437524 & $\mathbf{0 , 6 4 3 3 4 2}$ & $-0,638573$ & $-0,0084459$ & $\mathbf{0 , 0 2 6 2 0 1 4}$ \\
& $(1,704)$ & $\mathbf{( 6 , 9 5 4 )}$ & $(-1,012)$ & $(-0,3472)$ & $\mathbf{( 4 , 7 0 1 )}$ \\
2002.2 & $\mathbf{0 , 0 1 1 0 4 5 6}$ & $\mathbf{0 , 3 4 6 3 0 2}$ & $-0,520343$ & 0,0494592 & $\mathbf{0 , 0 1 0 6 5 2 8}$ \\
& $\mathbf{( 5 , 0 8 1 )}$ & $\mathbf{( 4 , 3 7 1 )}$ & $(-0,9549)$ & $(1,041)$ & $\mathbf{( 2 , 1 7 )}$ \\
2003.3 & $\mathbf{0 , 0 2 6 0 6 2}$ & $\mathbf{0 , 2 2 4 4 4 5}$ & $-1,03582$ & $\mathbf{0 , 2 7 7 1 3 4}$ & $\mathbf{0 , 0 2 3 9 8 2 3}$ \\
& $\mathbf{( 6 , 1 0 9 )}$ & $\mathbf{( 3 , 2 4 7 )}$ & $(-1,252)$ & $\mathbf{( 2 , 8 7 4 )}$ & $\mathbf{( 2 , 8 4 3 )}$ \\
2004.4 & $\mathbf{0 , 0 0 9 5 7 5 0 9}$ & $\mathbf{0 , 2 8 2 5 3}$ & $-0,334503$ & $\mathbf{0 , 1 3 3 5 1 1}$ & $\mathbf{0 , 0 1 2 3 4 0 2}$ \\
& $\mathbf{( 4 , 0 7 2 )}$ & $\mathbf{( 3 , 9 6 3 )}$ & $(-0,741)$ & $\mathbf{( 2 , 6 8 5 )}$ & $\mathbf{( 2 , 2 1 3 )}$ \\
2005.1 & $\mathbf{0 , 0 1 9 8 6 5 6}$ & $\mathbf{0 , 2 6 0 6 4 3}$ & $-0,728596$ & $\mathbf{0 , 3 5 0 3 6 3}$ & $\mathbf{0 , 0 2 9 3 9 9 3}$ \\
& $\mathbf{( 3 , 7 0 6 )}$ & $\mathbf{( 3 , 7 8 1 )}$ & $(-0,7369)$ & $\mathbf{( 2 , 8 6 )}$ & $\mathbf{( 2 , 3 8 )}$ \\
2006.2 & $\mathbf{0 , 0 0 8 7 7 0 4 8}$ & $\mathbf{0 , 2 6 5 4 3}$ & $-0,48932$ & $\mathbf{0 , 2 4 4 7 0 1}$ & $\mathbf{0 , 0 1 9 2 1 7 9}$ \\
& $\mathbf{( 2 , 8 4 7 3 )}$ & $\mathbf{( 3 , 9 8 5 )}$ & $(-0,7835)$ & $\mathbf{( 4 , 3 0 0 2 )}$ & $\mathbf{( 2 , 5 9 5 3 )}$ \\
2007.3 & $\mathbf{0 , 0 1 8 8 8 1 6}$ & 0,00273983 & $-1,45007$ & $\mathbf{0 , 7 3 4 3 5}$ & $\mathbf{0 , 0 5 3 0 2 1 3}$ \\
& $\mathbf{( 2 , 9 9 8 8 )}$ & $(0,5555)$ & $(-1,0013)$ & $\mathbf{( 4 , 6 5 8 2 )}$ & $\mathbf{( 3 , 1 0 7 1 )}$ \\
2008.4 & $\mathbf{0 , 0 1 2 3 2 3 1}$ & $\mathbf{0 , 1 8 5 5 4 4}$ & $-0,71962$ & 0,0306312 & 0,00969408 \\
& $\mathbf{( 3 , 8 8 9 2 )}$ & $\mathbf{( 2 , 5 1 6 1 )}$ & $(-1,1676)$ & $(0,4635)$ & $(1,1325)$ \\
2009.1 & $\mathbf{0 , 0 1 2 1 6 4 5}$ & $\mathbf{0 , 1 4 6 2 2 6}$ & $-0,86455$ & $\mathbf{0 , 4 0 6 3 7 3}$ & $\mathbf{0 , 0 5 2 5 6 8 6}$ \\
& $\mathbf{( 2 , 0 6 1 5 )}$ & $\mathbf{( 2 , 2 6 5 3 )}$ & $(-1,1615)$ & $\mathbf{( 3 , 1 3 8 9 )}$ & $\mathbf{( 3 , 4 8 9 7 )}$ \\
2010.2 & $\mathbf{0 , 0 0 7 1 0 5 1 5}$ & $\mathbf{0 , 1 8 6 0 0 3}$ & $-\mathbf{0 , 1 6 1 0 6 3}$ & 0,0993496 & $\mathbf{0 , 0 1 3 6 6 7}$ \\
& $\mathbf{( 3 , 4 6 5 6 )}$ & $\mathbf{3 , 9 3 7 1}$ & $(\mathbf{- 0 , 6 3 8 3})$ & $(2,4397)$ & $\mathbf{( 2 , 7 0 7 5 )}$ \\
2011.3 & $\mathbf{0 , 0 0 8 2 0 6 8 5}$ & $\mathbf{0 , 3 2 5 8 9 5}$ & $-0,357265$ & 0,0537371 & 0,00599505 \\
& $\mathbf{( 3 , 2 6 1 1 )}$ & $\mathbf{( 6 , 1 1 5 1 )}$ & $(-1,1203)$ & $(0,8716)$ & $(0,9237)$ \\
\hline
\end{tabular}

Fonte: Elaboração própria.

Tais resultados vão na mesma direção dos trabalhos expostos na literatura sobre o tema ${ }^{7}$ e têm como importante destaque o custo operacional das instituições financeiras como principal influência entre as variáveis microeconômicas, intrínsecas às firmas bancárias. Na segunda etapa de cálculo, foram utilizadas séries temporais com 44 observações para cada variável. Todas as variáveis foram significantes, à exceção da variável Ipca. A equação com as estimativas dos resultados está a seguir: ${ }^{8}$

$$
\begin{aligned}
\text { Spread puro }= & 0,008 \beta_{0}+0,010 \text { Selic }+0,005 \text { Ipca } \\
& +2,266^{-10} \text { Receita Val.Mob.-0,305Volatil. }-8,589^{-9} \text { LFTs }
\end{aligned}
$$

\footnotetext{
7 Ver Saunders e Schumacher (2000), Brock e Rojas Suárez (2000) e Maudos e Guevara (2004).

8 Os resultados que dão origem à equação de regressão exibida poderão ser consultados no Apêndice A deste trabalho.
} 
A variável Selic foi significativa no teste e apresentou o sinal positivo, como o esperado e de acordo com os resultados obtidos na literatura empírica. A volatilidade apresentou sinal negativo, oposto ao esperado para o comportamento da variância da taxa de juros. A inflação, medida pelo Ipca, não demonstrou significância no modelo. A possível justificativa para isso será dada na próxima seção. As variáveis que pretendiam explicar a influência das LFT no spread bancário no Brasil foram significantes. A receita de valores mobiliários apresentou sinal positivo, como o esperado, assim como o sinal negativo para LFT no mercado, dadas as justificativas acima descritas para esses resultados. Ambas as variáveis, contudo, apresentaram coeficientes baixos, o que indicaria uma reduzida influência sobre o spread. No entanto, deve-se levar em consideração que foram estatisticamente significativas na regressão mesmo sendo regredidas em conjunto com a Selic e a volatilidade, que são as variáveis reconhecidas pela literatura como as de maior impacto sobre o spread no Brasil.

\subsubsection{Interpretação dos Resultados}

Grande parte dos resultados obtidos nas regressões econométricas se mostrou alinhado com o que preconiza a literatura sobre o tema. Na primeira etapa, o custo é a variável mais significante para explicar as taxas praticadas de spread bruto pelos bancos para a concessão de empréstimos. Tal comportamento é o mesmo observado na literatura sobre o tema, tanto na nacional quanto na internacional.

Especificamente no Brasil, os custos enfrentados pelos bancos têm se tornado mais importantes para a operação das instituições financeiras nos últimos anos porque as fontes de receitas baseadas no período de alta inflação se extinguiram a partir da implementação do Plano Real. Mais recentemente, os ganhos obtidos com o cenário de altas taxas de juros também têm sofrido alterações, especialmente em 2011, o que naturalmente gera novas pressões para a alta de custos operacionais das instituições financeiras no país.

A constante gerada no cálculo - que é o spread puro, também como esperado, exibe sua importância para explicar o spread, o que pode ser interpretado pela relevância da inércia dos níveis de spread ao longo do tempo no Brasil. Em trabalhos como o de Silva, Oreiro e Paula (2007), quando o spread é regredido contra suas próprias defasagens, os testes econométricos exibem significativo grau de relevância. Ou seja, grande parte da trajetória da variável pode ser explicada por ela mesma no passado.

O índice de concentração de mercado IHH não foi significativo na regressão. Esse resultado encontra justificativa no estudo de Nakane (2003), em que é analisada a estrutura do mercado bancário brasileiro e tem como conclusão que os 
bancos no Brasil competem entre si, sem a existência de um tipo de modelo não competitivo de mercado.

Em relação às variáveis macroeconômicas, todas tiveram o comportamento esperado, à exceção da volatilidade de juros, que apresentou sinal oposto ao esperado, dado o cenário econômico de maior incerteza com a maior variância dos juros.

A variável Selic teve o comportamento e a significância esperada, o que confirma a alta correlação entre as trajetórias dessa variável em relação ao spread bancário, com base na hipótese do custo de oportunidade dos empréstimos. Como visto anteriormente, a importância da taxa de juros básica da economia foi encontrada em outros trabalhos empíricos reportados. Os elevados patamares em que a Selic se situou no passado recente do país e que, embora com tendência de queda, são ainda reconhecidamente elevados, acarreta a prática de elevadas taxas de retorno para grande parte das operações de empréstimos realizadas, mantendo o spread em patamares também elevados. De fato, as instituições financeiras tendem a utilizar a taxa de juros básica da economia como um piso para a concessão de crédito ao público, embutindo sobre ele um prêmio de risco. No caso brasileiro, como já destacado, a possibilidade de combinar alta rentabilidade e baixo risco através da aquisição de títulos públicos indexados à taxa Selic torna esta última concorrente da receita auferida com a atividade principal dos bancos, qual seja, a de intermediação financeira.

Vale destacar os resultados expressados pelas variáveis criadas e relacionadas à emissão dos títulos públicos atrelados à Selic, ou seja, as LFT. Ambas atingiram os níveis de significância exigidos pelos testes econométricos e exibiram os sinais esperados em relação ao comportamento do spread bancário. Tais resultados são importantes como evidências empíricas, pois a literatura que relaciona títulos públicos ao spread no Brasil é incipiente e não registra resultados através de exercícios econométricos sobre o tema. A partir desses resultados, há a indicação de que a dívida pública emitida tendo como indexador a própria taxa de juros da economia gera efeitos prejudiciais tanto na condução da política macroeconômica da economia brasileira, quanto no mercado de crédito.

Portanto, uma redução consistente que ocasione a extinção do estoque de títulos públicos atrelados à Selic deve ser uma política a ser perseguida pelo governo, favorecendo o intercâmbio para títulos lastreados em índices de preços e pré-fixados. Títulos de dívida pública com essas características já existem no Brasil, entretanto não encontram o mesmo nível de demanda por LFT, dado que estes últimos bastante atrativos (por suas características de ser um título indexado a taxa de juros que oferece uma proteção contra o risco de taxa de juros) no período analisado. Algumas medidas tomadas pelo governo brasileiro mais recentemente, como a mudança na composição da dívida pública (com redução na participação relativa das LFT no total da dívida), parecem indicar uma preocupação com o 
efeito prejudicial que as LFT exercem sobre a dívida pública e deveriam ser continuadas até que o perfil da dívida pública brasileira se torne independente da taxa básica de juros de curto prazo.

\section{Considerações Finais}

Este artigo objetivou relacionar o comportamento da dívida pública brasileira, historicamente ligada a um ambiente de instabilidade macroeconômica, com os níveis elevados de spread bancário no Brasil. Este trabalho confirma os indícios expostos em artigos anteriores sobre o tema e inclui a utilização de métodos empíricos para a medição dessa ligação entre títulos públicos atrelados à taxa básica de juros e spread bancário. Apesar da sensível queda ocorrida após a implementação do Plano Real, os níveis de spread bancário no Brasil permaneceram persistentemente elevados quando comparados aos níveis registrados em países em estágios similares de desenvolvimento, países desenvolvidos e até em relação a países que ainda têm o seu mercado de crédito e financeiro incipientes. A resiliência do nível spread no Brasil - motivação deste trabalho empírico e de outros já realizados - se deve a uma gama de fatores, tanto com aspectos considerados macroeconômicos quanto microeconômicos.

A taxa básica de juros da economia no Brasil, assim como o spread, se mostrou resistente a sólidas quedas no período analisado (2001-2011) em virtude, majoritariamente, do ambiente econômico em que a elevação da inflação leva à utilização do aumento na taxa Selic por parte do BCB a fim de desacelerar a atividade econômica no curto prazo, no contexto de operação do regime de metas de inflação no Brasil. A taxa de juros básica da economia tem sido utilizada como a principal ferramenta de política monetária na busca pelo controle da inflação, de acordo com o regime de metas estipulado.

A correlação existente entre dívida pública atrelada à taxa básica de juros através das LFT mostra seus efeitos deletérios não somente no perfil da dívida, mas também no nível do spread bancário praticado no Brasil. Os exercícios econométricos realizados neste trabalho corroboram a literatura sobre o tema. Essa relação deveria ser desenvolvida em novos trabalhos, a fim de gerar diferentes metodologias para aferir seus efeitos sobre a economia brasileira. A alteração no perfil da dívida pública a fim de extinguir as LFT poderia ser encarada de forma similar à dívida atrelada ao câmbio no passado. Ambas trazem impactos significativamente negativos para a economia como um todo (administração da dívida pública, canais de transmissão da politica monetária, estrutura a termo da taxa de juros, etc.).

A política monetária praticada no Brasil no período analisado neste trabalho, visando o atendimento às metas de inflação com o uso da taxa de juros básica como a variável que busca manter os níveis inflacionários, em um contexto em 
que parte da dívida é indexada à própria taxa Selic, gerou impactos negativos na dívida pública, bem como no mercado bancário brasileiro e de crédito através do auxílio à manutenção dos elevados níveis de spread bancário. Assim, enquanto a taxa de juros paga pelo governo se mantiver atraente para a aplicação em títulos públicos atrelados à mesma, os bancos brasileiros terão uma fonte rentável de receita com baixo risco. Isso impacta diretamente no spread praticado nas operações de concessão de crédito, tanto para pessoas físicas quanto jurídicas, o que auxilia a manutenção do spread em níveis acima dos praticados mundialmente.

O movimento recente feito pelo governo brasileiro no intuito de reduzir a participação de tais títulos na dívida pública do Brasil não só melhora o perfil da dívida em si, com a maior utilização de títulos pré-fixados ou atrelados a índices de preços, como também torna o ambiente de crédito bancário mais benéfico à concessão de novos empréstimos, à baixa das taxas de juros praticadas em tais operações e, em última instância, ao desenvolvimento econômico brasileiro.

\section{Referências}

AFANASIEFF, T.; LHACER, P.; NAKANE, M. The determinants of bank interest spread in Brazil. Money Affairs, v. 15, n. 2, p. 183-205, ago. 2002.

ARESTIS, P.; FERRARI FILHO, F.; PAULA, L. F. Inflation targeting in Brazil. International Review of Applied Economics, v. 25, n. 2, p. 127-148, maio 2011.

ARONOVICH, S. Uma nota sobre os efeitos da inflação e do nível de atividade sobre o spread bancário. Revista Brasileira de Economia, v. 48, n. 1, p. 125-140, mar.1994.

AVERBUG, A.; GIAMBIAGI, F. A crise brasileira de 1988/1999: origens e consequências. Rio de Janeiro: BNDES, maio 2000. (Texto para discussão, n. 77).

BANCO CENTRAL DO BRASIL. Relatório Anual. Brasília, DF: Banco Central, 2002.

Relatório de Economia Bancária e Crédito: Avaliação de 12 anos do Projeto Juros e

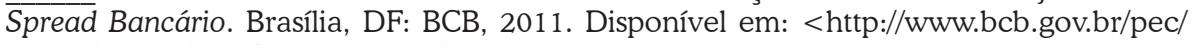
depep/spread/REBC_2011.pdf>. Acesso em: 13 dez. 2012.

BARBOSA, F. H. The contagion effect of public debt on monetary policy: the Brazilian experience. Revista de Economia Política, v. 26, n. 2, p. 231-238, jun. 2006.

BRANCO, R. Rentabilidade bancária no Brasil: uma breve análise no cenário recente. 2008. 39 f. Monografia (Ciências Econômicas) - Universidade do Estado do Rio de Janeiro, Rio de Janeiro, 2008.

BRASIL. Ministério da Fazenda. Secretaria do Tesouro Nacional. Dívida Pública Federal: Plano Anual de Financiamento 2012. Brasília, DF: Secretaria do Tesouro Nacional, jan. 2012. n. 12. p. 12-23. 
BRESNAHAN, T. The oligopoly solution concept is defined. California: Stanford University of California. 1982.

BROCK, P.; ROJAS SUÁREZ, L. Understanding the behavior of bank spreads in Latin America. Journal of Development Economics, v. 63, n. 1, p. 113-134, out. 2000.

CARDOSO, E. A crise monetária no Brasil: migrando da Âncora Cambial para o regime flexível. Revista de Economia Política, v. 21, n. 3, p. 146-167, set. 2001.

FERRARI FILHO, F.; PAULA, L. F. The legacy of the Real Plan and an alternative agenda for the Brazilian economy. Investigación Económica, v. 62, n. 244, p. 57-92, jun. 2003.

FUNGACOVA, Z.; POHOSYAN, T. Determinants of bank interest margins in Russia: Does bank ownership matter? Economic Systems, v. 35, n. 4, p. 481-495, Dec. 2011.

GREENE, W. Econometric Analysis. 5 ed. Upper Saddle River: Prentice Hall, 2003.

HO, T.; SAUNDERS, A. The determinants of bank interest margins: theory and empirical evidence. Journal of Financial and Quantitative Analysis, v. 16, n. 4, p. 581-600, Apr. 1981.

IBGE. Sistema financeiro: uma análise a partir das contas nacionais 1990-1995. Rio de Janeiro: IBGE, 1997.

JOHNSTON, J.; DINARDO, J. Econometric Methods. 5 ed. New York: McGraw Hill, 1997.

LAPLANE, M.; SARTI, F. Investimento direto estrangeiro e o impacto na balança comercial nos anos 90. Rio de Janeiro: Ipea, fev. 1999. (Textos para discussão, n. 629).

LAU, L. On identifying the degree of competitiveness from industry price and output data. California: Stanford University of Califórnia, 1982.

LEAL, R. M. Estrutura e determinantes do spread bancário no Brasil após 1994: uma análise da literatura empírica. In PAULA, L. F.; OREIRO, J. L. (Org.). Sistema Financeiro: Uma Análise do Setor Bancário Brasileiro. Rio de Janeiro: Campus/Elsevier, 2007. p. 221-251.

LEAL, R. M.; PAULA, L. F. Spread bancário: uma análise comparativa a partir da literatura internacional. Análise Econômica, v. 29, n. 56, p. 85-108, set. 2011.

LOPES, F. O mecanismo de transmissão de política monetária numa economia em processo de estabilização: notas sobre o caso do Brasil. Revista de Economia Política, v. 17, n. 3, p. 5-11, set. 1997.

MANHIÇA, F.; JORGE, C. O nível da taxa básica de juros e o spread bancário no Brasil: uma análise de dados em painel. Rio de Janeiro: Ipea, fev. 2012. (Texto para Discussão, n. 1710).

MAUDOS, J.; GUEVARA, J. Factors explaining the interest margin in the banking sectors of the European Union. Journal of Banking and Finance, v. 28, n. 9, p. 2259-2281, set. 2004.

NAKANE, M. Concorrência e spread bancário: uma revisão da evidência para o Brasil. In: BANCO CENTRAL DO BRASIL. Economia bancária e crédito: avaliação de 4 anos do projeto juros e spread bancário, Brasília, DF: BCB, 2003. p. 58-67. 
OREIRO, J. L.; AMARAL, R. A relação entre o mercado de dívida pública e a política monetária no Brasil. Revista de Economia Contemporânea, v. 12, n. 3, p. 491-517, dez. 2008.

PASTORE, A.; PINOTTI, M.; PAGANO, T. Limites ao crescimento econômico. Rio de Janeiro: INAE, 2009. (Estudos e Pesquisas, n. 346).

PAULA, L. F.; ALVES JR., A. Banking behaviour and the Brazilian economy after the Real Plan. Banca Nazionale del Lavoro. Quarterly Review, v. 56, n. 227, p. 337-365, dec. 2003.

PAULA, L. F.; PIRES, M. Determinantes macroeconômicos do spread bancário: uma análise preliminar para economias emergentes. In: PAULA, L. F.; OREIRO, J. (Ed.). Sistema Financeiro: uma análise do setor bancário brasileiro. Rio de Janeiro: Campus/Elsevier, 2007. 171-190.

REIS JÚNIOR, H. O. M.; PAULA, L. F.; LEAL, R. M. Decomposição do spread bancário no Brasil: uma análise do período recente. Economia, v. 14, n. 1A, p. 29-60, abr. 2013.

SAUNDERS, A.; SCHUMACHER, L. The determinants of bank interest rate margins: an international study. Journal of International Money and Finance, v. 19, n. 6, p. 813-832, dec. 2000 .

SILVA, G.; OREIRO, J. L.; PAULA, L.F. Spread bancário no Brasil: uma avaliação empírica recente. In: PAULA, L. F.; OREIRO, J. L. (Org.). Sistema financeiro: uma análise do setor bancário brasileiro. Rio de Janeiro: Campus; Elsevier, 2007. p. 191-220.

WOOLDRIGE, J. Introductory econometrics, 2. ed.. Mason: South-Western, 2002.

WORLD BANK; INTERNATIONAL MONETARY FUND. Indicators of financial structure, development, and soundness. In:

Washington, D.C.: IMF, 2011. p. 15-33. . Financial sector assessment: a handbook. 


\section{Apêndice A - Regressão do spread puro contra as variáveis macroeconômicas, testes estatísticos e regressão com erros robustos}

\section{Regressão da segunda etapa}

Tabela 2 - MQO, usando as observações 2001:1-2011:4 (T = 44) Variável dependente: spread_puro

\begin{tabular}{|c|c|c|c|c|}
\hline Variável & Coeficiente & Erro padrão & razão-t & p-valor \\
\hline Const & 0,00839495 & 0,00465322 & 1,8041 & $0,07914 *$ \\
\hline Selic & 0,0099402 & 0,00382741 & 2,5971 & $0,01330 * *$ \\
\hline Ipca & 0,00458842 & 0,0117398 & 0,3908 & 0,69810 \\
\hline rec val Mob & $2,26636 \mathrm{e}-010$ & $8,47891 \mathrm{e}-011$ & 2,6729 & $0,01102 * *$ \\
\hline Volatilidade & $-0,305025$ & 0,0998139 & $-3,0559$ & $0,00409 * * *$ \\
\hline LFTS_no_mercado & $-8,58896 \mathrm{e}-09$ & $4,89088 \mathrm{e}-09$ & $-1,7561$ & $0,08713 *$ \\
\hline Média variável dependente & \multicolumn{2}{|c|}{$\begin{array}{lll}\text { e } & 0,011142 & \text { D }\end{array}$} & variável. & 0,007623 \\
\hline Soma resíduos. quadrados & \multicolumn{2}{|c|}{0,001695} & a regressão & 0,006680 \\
\hline R-quadrado & 0,321530 & \multicolumn{2}{|c|}{ R-quadrado ajustado } & 0,232257 \\
\hline $\mathrm{F}(5,38)$ & \multirow{2}{*}{$\begin{array}{l}3,601672 \\
161,1752\end{array}$} & \multicolumn{2}{|c|}{ P-valor(F) } & 0,009172 \\
\hline Log da verossimilhança & & \multicolumn{2}{|c|}{ Critério de Akaike } & $-310,3505$ \\
\hline Critério de Schwarz & $-299,6454$ & Critéri & an-Quinn & $-306,3805$ \\
\hline Rô & $-0,303909$ & Durbin & & 2,531773 \\
\hline
\end{tabular}

Fonte: Elaboração própria. 


\section{Teste de White para heterocedasticidade}

Tabela 3 - MQO, usando as observações 2001:1-2011:4 ( $\mathrm{T}=44)$

Variável dependente: uhat ${ }^{\wedge} 2$

\begin{tabular}{|c|c|c|c|c|c|}
\hline Variável & Coeficiente & ErTo padrão & razão-t & p-valor & \\
\hline const & 0,000228519 & 0,000228441 & -1 & 0,3276 & \\
\hline selic & 0,000442031 & 0,000292621 & 1,511 & 0,1445 & \\
\hline ipca & $-5,76 \mathrm{E}-05$ & 0,000729424 & $-0,07903$ & 0,9377 & \\
\hline rec_val__Mob_ & $1,01 \mathrm{E}-12$ & $6,12 \mathrm{E}-12$ & 0,1654 & 0,8701 & \\
\hline LFTS_no_mercado & $-1,13 \mathrm{E}-10$ & $3,14 \mathrm{E}-10$ & $-0,3603$ & 0,7219 & \\
\hline Volatilidade & 0,00918308 & 0,0083937 & 1,094 & 0,2853 & \\
\hline sq_selic & $4,66 \mathrm{E}-05$ & $8,26 \mathrm{E}-05$ & 0,5644 & 0,578 & \\
\hline $\mathrm{X} 2 \_\mathrm{X} 3$ & $-0,00063948$ & 0,000783477 & $-0,8162$ & 0,4228 & \\
\hline X2_X4 & $1,03 \mathrm{E}-11$ & $4,17 \mathrm{E}-12$ & 2,475 & 0,0211 & $* *$ \\
\hline $\mathrm{X} 2 \_\mathrm{X} 5$ & $-1,89 \mathrm{E}-10$ & $2,47 \mathrm{E}-10$ & $-0,7645$ & 0,4523 & \\
\hline $\mathrm{X} 2 \_\mathrm{X} 6$ & $-0,0192786$ & 0,00633748 & $-3,042$ & 0,0058 & $* * *$ \\
\hline sq_ipca & 0,00119519 & 0,00148681 & 0,8039 & 0,4297 & \\
\hline X3_X4 & $-1,77 \mathrm{E}-12$ & $9,76 \mathrm{E}-12$ & $-0,1817$ & 0,8574 & \\
\hline X3_X5 & $-3,97 \mathrm{E}-10$ & $8,44 \mathrm{E}-10$ & $-0,4706$ & 0,6423 & \\
\hline $\mathrm{X} 3 \_\mathrm{X} 6$ & 0,00944503 & 0,0125175 & 0,7545 & 0,4582 & \\
\hline sq_rec_val_Mob_ & 0,00000 & 0,00000 & 2,041 & 0,0529 & $*$ \\
\hline X4_X5 & 0,00000 & 0,00000 & $-1,47$ & 0,155 & \\
\hline X4_X6 & $-4,84 \mathrm{E}-10$ & $2,02 \mathrm{E}-10$ & 2,394 & 0,0252 & $* *$ \\
\hline sq_LFTS_no_merca & 0,00000 & 0,00000 & 1,055 & 0,3025 & \\
\hline X5_X6 & $1,66 \mathrm{E}-08$ & $9,49 \mathrm{E}-09$ & 1,745 & 0,0943 & $*$ \\
\hline sq_Volatilidade & 0,158722 & 0,115675 & 1,372 & 0,1833 & \\
\hline
\end{tabular}

Fonte: Elaboração própria.

\section{Teste de distribuição normal dos resíduos}

Tabela 4 - Distribuição de frequência para uhat 1, observações 1-44 número de classes $=7$, média $=-1,83329 \mathrm{e}-018$, desvio padrão $=$ 0,00667951

\begin{tabular}{|c|c|c|c|c|c|}
\hline Intervalo & Ponto Médio & Frequência & Relação & Acumulado & \\
\hline$<-0,011927$ & $-0,014121$ & 1 & $2,27 \%$ & $2,27 \%$ & \\
\hline$-0,011927--0,0075384$ & $-0,0097325$ & 3 & $6,82 \%$ & $9,09 \%$ & $* *$ \\
\hline$-0,0075384--0,0031502$ & $-0,0053443$ & 12 & $27,27 \%$ & $36,36 \%$ & $* * * * * * * * *$ \\
\hline$-0,0031502-0,001238$ & $-0,00095614$ & 9 & $20,45 \%$ & $56,82 \%$ & $* * * * * * *$ \\
\hline $0,0012380-0,0056261$ & 0,003432 & 8 & $18,18 \%$ & $75,00 \%$ & $* * * * * *$ \\
\hline $0,0056261-0,010014$ & 0,0078202 & 9 & $20,45 \%$ & $95,45 \%$ & $* * * * * * *$ \\
\hline $\begin{array}{l}>=0,010014 \\
\text { Teste para a hipótese nula de distribuição } \\
\text { normal: } \\
\text { Qui-quadrado }(2)=0,769 \text { com } p \text {-valor } \\
0,68085\end{array}$ & 0,012208 & 2 & $4,55 \%$ & $100,00 \%$ & $*$ \\
\hline
\end{tabular}

Fonte: Elaboração própria. 


\section{Teste de Breusch-Godfrey para autocorrelação de primeira ordem}

Tabela 5 - MQO, usando as observações 2001:1-2011:4 ( $\mathrm{T}=44)$ Variável dependente: uhat

\begin{tabular}{|c|c|c|c|c|}
\hline Variável & Coeficiente & Erro padrão & razão-t & p-valor \\
\hline Const & 0,00017084 & 0,00446361 & 0,03827 & 0,9697 \\
\hline Selic & $-0,0005776$ & 0,00368135 & $-0,1569$ & 0,8762 \\
\hline ipca & 0,00343772 & 0,0113806 & 0,3021 & 0,7643 \\
\hline rec_val_Mob & $-5,38 \mathrm{E}-11$ & $8,53 \mathrm{E}-11$ & $-0,6304$ & 0,5323 \\
\hline LFTS_no_mercado & $-8,84 \mathrm{E}-11$ & 4,69E-09 & $-0,01885$ & 0,9851 \\
\hline Volatilidade & 0,0432897 & 0,0979745 & 0,4418 & 0,6612 \\
\hline uhat_1 & $-0,348425$ & 0,167809 & $-2,076$ & $0,0449 * *$ \\
\hline \multicolumn{5}{|c|}{ R-quadrado não ajustado $=0,104357$} \\
\hline \multirow{2}{*}{\multicolumn{5}{|c|}{$\begin{array}{l}\text { Estatística de teste: } \mathrm{LMF}=4,311090 \\
\text { com } p \text {-valor }=\mathrm{P}(\mathrm{F}(1,37)>4,31109)=0,0449\end{array}$}} \\
\hline & & & & \\
\hline \multicolumn{5}{|c|}{ Estatística alternativa: $\mathrm{TR}^{\wedge} 2=4,591696$} \\
\hline \multicolumn{5}{|c|}{ com $p$-valor $=\mathrm{P}($ Qui-quadrado $(1)>4,5917)=0,0321$} \\
\hline \multicolumn{5}{|c|}{ Ljung-Box $Q^{\prime}=4,22245$} \\
\hline com $p$-valor $=P(Q u i-q$ & $>4,22245)=0$ & 0399 & & \\
\hline
\end{tabular}

Fonte: Elaboração própria.

\section{Teste Aumentado de Dickey-Fuller para spread_puro}

Tabela 6 - Teste Aumentado de Dickey-Fuller para spread_puro

incluindo 5 defasagens de (1-L)spread_puro

(o máximo foi 9, critério AIC modificado)

dimensão de amostragem 38

hipótese nula de raiz unitária: $\mathrm{a}=1$

teste com constante

modelo: $(1-\mathrm{L}) \mathrm{y}=\mathrm{b} 0+(\mathrm{a}-1) * \mathrm{y}(-1)+\ldots+\mathrm{e}$

coeficiente de $1^{\mathrm{a}}$ ordem para e: $-0,097$

diferenças defasadas: $\mathrm{F}(5,31)=0,923[0,4795]$

valor estimado de (a - 1): - 0,510485

estatística de teste: tau_c(1) $=-1,14602$

p-valor assintótico 0,6997

com constante e tendência

modelo: (1-L)y $=\mathrm{b} 0+\mathrm{b} 1 * \mathrm{t}+(\mathrm{a}-1)^{*} \mathrm{y}(-1)+\ldots+\mathrm{e}$

coeficiente de $1^{\text {a }}$ ordem para e: 0,001

valor estimado de (a - 1): -1,27419

continua... 
conclusão.

estatística de teste: tau_ct(1) $=-4,96751$

p-valor assintótico 0,0001

Fonte: Elaboração própria.

\section{Regressão da segunda etapa com erros robustos}

Tabela 7 - Modelo 2: MQO, usando as observações 2001:1-201 1:4 ( $=44)$

Variável dependente: spread_puro

Erros padrão HAC, largura de banda 2 (Núcleo de Bartlett)

\begin{tabular}{|c|c|c|c|c|c|}
\hline Variável & Coeficiente & Erro padrão & razão-t & p-valor & \\
\hline Const & 0,00839495 & 0,00355741 & 2,3598 & 0,02352 & $* *$ \\
\hline Selic & 0,0099402 & 0,00270599 & 3,6734 & 0,00073 & $* * *$ \\
\hline Ipca & 0,00458842 & 0,00988036 & 0,4644 & 0,64501 & \\
\hline rec_val_Mob_ & $2,27 \mathrm{E}-10$ & $7,76 \mathrm{E}-11$ & 2,9187 & 0,00588 & $* * *$ \\
\hline LFT_no_mercad & $-8,59 \mathrm{E}-09$ & $4,21 \mathrm{E}-09$ & $-2,0394$ & 0,04841 & $* *$ \\
\hline Volatilidade & $-0,305025$ & 0,110415 & $-2,7625$ & 0,00879 & $* * *$ \\
\hline Média variável dependente & 0,011142 & & Desvio Padrão variável dependente & 0,007623 & \\
\hline Soma resíduos quadrados & 0,001695 & & Erro Padrão da regressão & 0,00668 & \\
\hline R-quadrado & 0,32153 & & R-quadrado ajustado & 0,232257 & \\
\hline $\mathrm{F}(5,38)$ & 5,103601 & & P-valor(F) & 0,001122 & \\
\hline Log da verossimilhança & 161,1752 & & Critério de Akaike & $-310,3505$ & \\
\hline Critério de Schwarz & $-299,6454$ & & Critério Hannan-Quinn & $-306,3805$ & \\
\hline rô & $-0,303909$ & & Durbin-Watson & 2,531773 & \\
\hline
\end{tabular}

Fonte: Elaboração própria.

Recebido em: 13/11/13.

Aceito em: 23/01/14. 